\title{
ORGANIZATIONAL JUSTICE AND AFFECTIVE COMMITMENT TO CHANGE IN EMPLOYEES OF MULTIFINANCIAL SERVICE COMPANY
}

\author{
Safitri Primawidi, Wustari L. Mangundjaya \\ Program Magister Psikologi Terapan SDM-KM, Fakultas Psikologi, Universitas Indonesia \\ Jl. Lingkar Kampus Raya Blok Mawar No.5, Kota Depok, Jawa Barat Indonesia 16424 \\ safitriprimawidi@gmail.com
}

\begin{abstract}
The aim of the study is to investigate the role of organizational justice to affective commitment to change. The study was conducted based on data collected from 42 employees working in head office of multifinancial service company. It is made up of 16 males and 26 females' employees. Affective commitment to change was measured using Herscovitch and Meyer's Affective Commitment to Change Scale (6 items; $\alpha=.828$ ). While organizational justice was measured using Colquitt's Organizational Justice Scale (20 items; $\alpha=.905$ ). The hypotheses were tested using multiple regressions. The result showed $R^{2}$ of .821 , meaning that $82 \%$ of affective commitment to change can be explained by organizational justice. Among four dimensions of organizational justice, procedural justice has the most influence and significant role on affective commitment to change ( $\beta=$ $.445, p<.001)$, followed by distributive justice $(\beta=.336, p<.001)$. The findings of the study demonstrated that organizational justice has positive significant impact on affective commitment to change, particularly distributive and procedural justice. Based on this study, in order to develop affective commitment to change in these multifinance company employees, to design intervention to increase organizational justice is neccessary.
\end{abstract}

Keywords: affective commitment to change; organizational justice; change

\begin{abstract}
Abstrak
Penelitian ini bertujuan untuk melihat peran keadilan organisasi terhadap komitmen afektif untuk berubah. Responden penelitian adalah 42 karyawan kantor pusat perusahaan jasa pembiayaan, terdiri dari 16 orang responden laki-laki dan 26 orang responden perempuan. Komitmen afektif untuk berubah diukur menggunakan Skala Komitmen Afektif untuk Berubah dari Herscovitch \& Meyer (6 item; $\alpha=0,828$ ). Sedangkan keadilan organisasi diukur menggunakan Skala Keadilan Organisasidari Colquitt (20 item; Cronbach's $\alpha=0,905$ ). Penelitian ini dianalisis dengan menggunakan analisis regresi berganda. Hasil analisis menghasilkan nilai $R^{2}$ sebesar 0,821 yang menunjukkan bahwa $82 \%$ skor komitmen afektif untuk berubah dapat dijelaskan oleh keadilan organisasi. Dari empat dimensi keadilan organisasi, terlihat bahwa keadilan prosedural memiliki pengaruh paling besar terhadap komitmen afektif untuk berubah $(\beta=0,445, p<0,001)$, diikuti oleh keadilan informasional $(\beta=0,336, p<0,001)$. Kesimpulan yang dapat ditarik dari penelitian ini adalah keadilan organisasi memiliki pengaruh positif dan signifikan terhadap komitmen afektif untuk berubah, terutama keadilan prosedural dan informasional. Berdasarkan hasil penelitian tersebut, untuk dapat meningkatkan komitmen afektif untuk berubah pada karyawan di bidang jasa pembiayaan, dapat dirancang intervensi yang dapat meningkatkan keadilan organisasi.
\end{abstract}

Kata kunci: komitmen afektif untuk berubah; keadilan organisasi; perubahan

\section{INTRODUCTION}

In this $21^{\text {st }}$ century, the changing become part of all life's aspect; yet become essential element in work environment. Changing become individual and organizational daily facing phenomena (Foster, 2010). The current work environment is characterized by numerous organizational changes that adjust to business growth, innovation, globalization, complex policies, competition, and the development of customer tastes (Pasmore, 2011). 
Although organizational change is inevitable and the rhythm is accelerating, in reality around $70 \%$ of organizational change is ineffective (Washington \& Hacker, in Cinite, Dugbury, \& Higgins, 2009). Various challenges faced by organizations in implementing change, and employee response to change is one of the determinants of whether change implementation will succeed or not (Foster, 2010).

In this case, to change is expressed as the most significant factor in employee support for change initiatives (Herscovitch \& Meyer, 2002; Neves, 2009; Choi, 2011). Conner and Patterson are emphasizing of commitment to change in transformation (in Parish, Cadwallader \& Busch, 2008) which states that the most common factor causing change deterioration is lack of employee commitment. Employees with low commitment to change tend to quit the job, work absence, poor of organizational citizenship behavior in terms of work performance.

Mangundjaya (2013) vocalized the essential and fundamental role of commitment to change in order to fully achieve the organizational change, because commitment to change is one of the most important factors that influence employee behavior to underpinning the change (Choi, 2011; Elias, 2009 in Indriastuti \& Fachrunnisa, 2019). Commitment to change in the implementation of change becomes significant on the ground that commitment to change not only mirrors a positive attitude towards change but also harmony with change, a propensity to sustain change, a willingness to strive for fruitful implementation of transformation (Heroldz \& Caldwell, 2007), and change acceleration (Parish et al., 2008). Based on this explanation, it can be assumed that the lack of employee support for change can hamper the adoption of changes in the form of reluctance to be actively involved in changes to the rejection of change.

Herscovitch and Meyer (2002) defined commitment to change as a power (mind) that binds individuals to do the things needed for successful change. Furthermore, they divide commitments to change into three specifically affective commitment to change whereas employees feel the need to support change because they believe in the positive value of the change, continuance commitment to change where employees support change for the reason if they don't then it produces negative impacts, and normative commitment to change where employees feel that supporting change is an obligation part of the organization.

Furthermore, Herscovitch and Meyer (2002) stated affective commitment to change is considered to produce the most positive performance compared to the other two dimensions of commitment to change. Studies shows that affective commitment to change will persuade individual to display behavior that supports change (Bakari, Hunjra, \& Niazi, 2017; Machin, Fogarty, \& Bannon, 2009; Shin, Taylor, \& Seo, 2012), such as adhering the change, giving more effort than expected related to change, and inviting others to participate in change (Meyer et al, 2007; Michaelis, Steigmaier, and Sonntag, 2009; Baraldi et al., 2010; Jaros, 2010). In addition, research conducted by Parish et al., (2008) also states that affective commitment to change has a positive influence on individual learning processes, emotional attachment, successful organizational change, and accelerated organizational change.

Mangundjaya (2016) expressed two factors that shape affective commitment to change, namely internal factors and external factors. Various studies have been conducted to find out the external factors that affect affective commitment to change in employees in organizations, including organizational justice (Stjernen, 2009; Fuchs \& Edwards, 2011), superiors and subordinate relationships (Parish et al., 2008), communication of change (Mangundjaya, 2014), transformational leadership (Herold et al, 2007; Liu, 
2010), and trust in organizations (Mangundjaya, 2015).

Research on organizational justice shows this variable as a predictor of openness, acceptance, cooperation, and satisfaction with higher change (Blader \& Tyler; Greenberg; Wanberg \& Banas; in Foster, 2010). Research conducted by Bernerth, Armenakis, Feild, \& Walker (2007); Herold, Fedor, and Caldwell (2007); Foster (2010); Michel, Stegmaier, \& Sonntag (2010); and Mangundjaya (2014) confirmed a significant relationship between organizational justice and commitment to change. Foster (2010) states that when faced with change, employees who have a high perception of organizational justice have a higher willingness to commit and sense they be required to have a commitment to change.

Organizational justice refers to the individual's perception of fairness in the organization (Foster, 2010). According to Miao, Sun, Hou, and Li (2012), the perception of organizational justice points out to the extent to which employees feel their work procedures, interactions and work results are respected to be fair, and the relevance of justice as an occurrence of justice within the organization not only affects the perception of fairness but also affect employee attitudes and behavior. Further, Colquitt (2001) states four dimensions of organizational justice, to be precise distributive justice, procedural justice, interpersonal justice and informational justice.

According to Leventhal (in Colquitt, 2001), distributive justice focuses on justice related to decision outcomes. The results of the intended decision include monetary and nonmonetary forms (such as salaries, benefits, promotions, etc.) that employees receive in return for their contributions to the workplace (Mensah, Asiamah, \& Mireku, 2016). Employees compare with their coworkers the ratio between the effort they provide and the output they achieve. The evaluation made based on fairness compensation for the effort they gave by with colleagues as a comparison. If the input and output ratio is equal for all employees, subsequently it can be said that distributive justice has been achieved in the organization (Ohana \& Meyer, 2016). As maintained by Leventhal (in Colquitt, 2001), procedural justice focuses on fairness in the process leading to the outcome of decisions, explicitly employee perceptions of fairness in the processes, policies and procedures of decisions and the application of rules to employees and management (Day, 2011; Aggarwal-Gupta and Kumar, 2010). Greenberg (in Colquitt, 2001) stated interpersonal justice reflects the degree to which employees are indulgence with courtesy, dignity, and respect by the authorities or third parties involved in executing procedures or determining outcomes. Informational justice focuses on explanations given to employees that contain information about reasonable explanation about the use of procedures or the explanation about delivering the decisions in certain way (Greenberg, in Colquitt, 2001).

Currently, changes in the whole business industry also come about in the automotive finance industry. Slowing economic growth that occurred in the last three years has had a major impact on the market of finance companies, especially commercial or commercial vehicle financing. It causing increasingly fierce competition and financing companies' difficulties, which among others are marked by a decline in profit financing. Data from the Financial Services Authority (m.bisnis.com, 2016) shown the mining sector financing receivables in July 2016 fell by $27.12 \%$ when compared to financing in the same period of the previous year. Changes have also been experienced by companies in the field of financing services, one of which is PT. Z. Based on our' observations and interviews with $\mathrm{HR}$ managers at PT. Z, since 2016, changes have experienced including in the reduction of employees, application of information 
systems and changes in organizational structure which include changes in duties and job descriptions and the formation of new sections and positions. In addition, the company also faces an acquisition plan. Based on these data, it is interesting to investigate specifically the role of organizational justice towards affective commitments in finance service companies that are undergoing significant changes.

Based on the above mentioned theoretical and conceptual framework following research questions have been proposed: (1) is there a positive role for organizational justice for affective commitment to change among finance service company employees? And (2) which organizational justice dimension has the strongest role with affective commitment to change in finance company employees? Further, based on the questions above, the hypotheses proposed is as follows:

(H1) Organizational justice has a positive influence on affective commitment to change (H2) Procedural justice has a positive role in affective commitment to change

(H3) Distributive justice has a positive role in affective commitment to change

(H4) Interpersonal justice has a positive role in affective commitment to change
(H5) Informational justice has a positive role in affective commitment to change.

\section{METHOD}

There were 42 employees of the Head Office of a national multifinancial service company (PT. Z) participated in this study. Convenient sampling technique was used to collect the data from these employees. Employees have at least 2 years of working experiences with permanent status were requested to fill up the questionnaire. The organization change has been occurred for two years, so the employees are deemed to have felt the change process.

Instruments used in this study are Commitment to Change Scale and Organizational Justice Scale. The affective commitment to change instrument developed by Herscovitch and Meyer (2002) which was translated into Indonesian and modified into six scales (optional) by Mangundjaya (2012). This instrument consists of 6 items that include dimensions of affective commitment to change with a reliability coefficient of .828. An example of an item for Change is 'I believe this change is important'.

Table 1.

The Blue Print of Organizational Justice Scale

\begin{tabular}{lll}
\hline Dimension & $\begin{array}{l}\text { Number } \\
\text { of items }\end{array}$ & Item's example \\
\hline Procedural justice & $1,2,3$, & Company regulations are applied consistently \\
& $4,5,6,7$ & \\
Distributive justice & $8,9,10$, & The rewards that I receive are consistent with \\
& 11 & the results of my performance \\
Interpersonal justice & 12,13, & My supervisor treats me politely \\
& 14,15 & \\
Informational justice & $16,17, \quad$ My supervisor explained the decision-making \\
& 18,19, & procedure thoroughly \\
& 20 & \\
\hline
\end{tabular}

The organizational justice developed by Colquitt (2001) which was translated into Indonesian and modified into six scales by Yulianti (2017). This instrument consists of
20 items that include dimensions of procedural justice, distributive justice, interpersonal justice, and informational justice with a reliability coefficient of .905 . 
The SPSS 17.0 and statistical software packages was used for data analysis. The grid of the Organizational Justice measurement tool can be seen in the Table 1. The blue print of organizational justice scale was shown at Table 1.

A six-point Likert scale $(1=$ strongly disagree to $6=$ strongly agree) was used. In summary, the higher the participant's score, the higher the perceived organizational justice.

\section{RESULTS AND DISCUSSION}

\section{Descriptive analysis}

Based on data analyses using the SPSS 17.0, the mean value of affective commitment to change for all participants was 3.50 and SD 92. The average of the total score for affective commitment to change has a minimum score of 2.33 and a maximum score of 5.33. Further, the demographic profile shown that the manager level has the highest mean affective commitment to change $(M=4.49)$. While the lowest mean affective commitment to change is shown by the age category below 29 years, which is 3.07. Then, we conducted a different test to find out whether there were differences in the data that showed the effect of demographic data on affective commitment to change and the perception of organizational justice.

Table 2.

Profile of Affective Commitment to Change and Organizational Justice based on Participants Demographic Data

\begin{tabular}{|c|c|c|c|c|c|c|c|c|c|c|}
\hline \multirow[b]{2}{*}{ Description } & \multicolumn{5}{|c|}{ Affective commitment to change } & \multicolumn{5}{|c|}{ Organizational justice } \\
\hline & Mean & SD & $t / F$ & $d f$ & Sig. & Mean & SD & $t / F$ & $d f$ & Sig. \\
\hline Gender & & & $\mathrm{t}=1,35$ & 40 & 0,184 & & & $\mathrm{t}=1,13$ & 40 & 0,264 \\
\hline Male & 3,26 & 0,93 & & & & 3,40 & 0,82 & & & \\
\hline Female & 3,65 & 0,89 & & & & 3,68 & 0,76 & & & \\
\hline Age & & & $t=-2,36$ & 40 & $0,023^{*}$ & & & $t=-2,53$ & 40 & $0,015^{*}$ \\
\hline$\leq 29$ & 3,07 & 0,69 & & & & 3,18 & 0,57 & & & \\
\hline $30-49$ & 3,74 & 0,95 & & & & 3,79 & 0,81 & & & \\
\hline Education & & & $t=-0,60$ & 40 & 0,552 & & & $t=-0,39$ & 40 & 0,701 \\
\hline Diploma 1-3 & 3,35 & 0,90 & & & & 3,49 & 0,75 & & & \\
\hline $\mathrm{D} 4 / \mathrm{S} 1$ & 3,55 & 0,93 & & & & 3,60 & 0,80 & & & \\
\hline Job level & & & $\mathrm{F}=6,89$ & $\mathrm{df} 1=2$ & $0,003^{*}$ & & & $F=6,73$ & $\mathrm{df} 1=2$ & $0,003 *$ \\
\hline Staff & 3,21 & 0,82 & & df $2=39$ & & 3,33 & 0,68 & & df $2=39$ & \\
\hline Supervisor & 4,08 & 0,73 & & & & 4,08 & 0,78 & & & \\
\hline Manager & 4,49 & 0,84 & & & & 4,38 & 0,63 & & & \\
\hline Years of work & & & $\mathrm{t}=-2,39$ & 40 & $0,021 *$ & & & $t=-2,53$ & 40 & $0,015^{*}$ \\
\hline $2-10$ years & 3,32 & 0,86 & & & & 3,39 & 0,73 & & & \\
\hline$>10$ years & 4,08 & 0,88 & & & & 4,03 & 0,74 & & & \\
\hline
\end{tabular}

Note: *significant at $p<.05$

The results indicated that the score of affective commitment to change in each group of years of work, age and position level had a significant difference. In addition, the value of affective commitment to change in each group in the categories of gender, work units, and educational background did not show a significant 
difference. Particularly, years of work, age and position level had influences on the

For organizational justice, it shown a minimum score of 2.10 and a maximum score of 5.25, the mean score of participants' value of affective commitment to change. The results can be seen in Table 2 . organizational justice is 3.57 and SD is .78. General description of organizational justice results is shown in Table 2.

Table 3.

General Description of Organizational Justice Variable

\begin{tabular}{lccccc}
\hline \multicolumn{1}{c}{ Dimension } & Mean & Median & $S D$ & Minimum & Maximum \\
\hline Organizational justice & 3.57 & 3.42 & .78 & 2.10 & 5.25 \\
Procedural justice & 3.12 & 3.00 & .96 & 1.00 & 5.00 \\
Distributive justice & 2.69 & 2.00 & 1.40 & 1.00 & 6.00 \\
Interpersonal justice & 4.90 & 5.00 & .72 & 2.50 & 6.00 \\
Informational justice & 3.85 & 3.60 & 1.16 & 2.00 & 5.80 \\
\hline
\end{tabular}

\section{Main analysis}

To examine the effect of organizational justice on affective commitment to change, regression analysis is used. Result obtained values $\mathrm{R} 2=.821, \mathrm{~F}(1.40)=184.07, \mathrm{p}<.05$ which means $82 \%$ affective commitment to change can be explained by organizational justice, and the rest can be explained by other factors not investigated at this study. Hypothesis 1 was therefore accepted. The organizational justice significantly influences the affective commitment to change.

Table 4.

Regression Analysis of Organizational Justice and Affective Commitment to Change

\begin{tabular}{lccccc}
\hline Dimension & $\begin{array}{c}\text { Pearson's } \\
\text { Correlation }\end{array}$ & $R^{2}$ & $B$ & $\begin{array}{c}\beta \\
\text { (Standardized } \\
\text { coefficients) }\end{array}$ & Sign. \\
\hline Organizational justice & .804 & .821 & & & $<.001^{* *}$ \\
Procedural justice & .575 & & .364 & .445 & $<.001^{* *}$ \\
Distributive justice & .764 & & .300 & .305 & $.001^{* *}$ \\
Interpersonal justice & .497 & & .230 & .121 & .150 \\
Informational justice & .524 & & .319 & .336 & $<.001^{* *}$ \\
\hline
\end{tabular}

** significant at $p<.01$

From the regression analysis in Table 4 , it tested that procedural justice; distributive justice and informational justice have positive significant contributions on affective commitment to change. It was indicating by the Beta coefficient $(\beta)$ of $0.445,0.305$ and 0.336 with a significance level of less than 0.001. In other words, it can be seen that an increase in procedural, distributive and informational justice scores will be followed by an increase in the affective commitment score to change. Therefore, Hypotheses 2-3 were confirmed. Both of procedural justice and distributive justice have significant influence on affective commitment to change. Hypothesis 4 was not supported, means that interpersonal justice has not significantly influence the affective commitment to change. Last, Hypothesis 5 is accepted. Informational justice has significant influence on affective commitment to change.

The current study found positive significant role of organizational justice towards affective commitment to change in financial service company employees. It supported 
previous research conducted by Foster (2010), Fuchs (2011) and Mangundjaya (2014) which shows that there was a positive relationship and influence from organizational justice to affective commitment to change. The findings also shown the dimensions of procedural, distributive and informational justice have a positive influence on affective commitment to change. Similarly, with research conducted by Foster (2010) which states the positive influence of the dimensions of organizational justice on affective commitment to change.

The perceived of lack of organizational justice felt by the employees of finance service companies shown that employees felt threat unfair by the company. Fuchs (2011) stated that when faced with change, employees tend to seek security in organizational justice. It will affect their reaction to change. In other words, employees who treat fairly will have attitudes and commitments that reflect a commitment to change. Otherwise, compiling organizational decisions and company policies considering unfairly then the employees could display unsupportive behavior such as being reluctant to be involved in changes, as was found in this study.

Based on the Beta values in table 4 , it suggests that the procedural justice become the most influencing dimension to achieve affective commitment to change. The result is strengthening the procedural justice plays an important role in helping employees to have affective commitment to change, with facilitate equal opportunity and effective communication during change process (Tsai \& Harrison, 2019).

To the company, the results of this study could encourage to develop policies that can improve organizational justice and affective commitment to change. Baldwin (2006) affirmed that the influence factors that influence perceptions of organizational justice mostly concentrate on employee communication and involvement. Further, in addressing low level of organizational justice, the principle of voice is an essential to be fulfilled because it has a preventive and corrective function in improving the perception of organizational justice. The employee involvement in decision making is one technique to stimulate employee assist for change (Van der Voet, Kuipers \& Groeneveld, 2015; Rogiest, Segers, \& Witteloostuijn, 2015). Though the final decisions feel unsatisfied for employees, but providing opportunities for employees to be involved in the decision-making process can reduce employee discomfort with the results (de Coninck, 2010). Hence, the ability of company management (in this case represented by managers) to communicate and implement procedures in order to perceived fairly is expected to create and maintain procedural justice thus be able improve the employees' perception of organizational justice and affective commitment to change.

\section{CONCLUSION}

The results of this study confirmed the significant positive role between organizational justice with affective commitment to change. Also, it implied the significant role of three dimension of organizational justice (procedural justice, distributive justice and transformational justice) to affective commitment to change. Meanwhile, participants' demographic analysis result found years' work; job level and age have significant effect to organizational justice and affective commitment to change. Future studies are recommended to explore more about role of organizational justice on Multifinancial Service Company using more representative samples and objective measurement.

\section{REFERENCES}

Aggarwal-Gupta, M., \& Kumar, R. (2010). Look who's talking! Impact of 
communication relationship satisfaction on justice perceptions. Vikalpa, 35(3), 55-66. doi:10.1177\%2F0256090920100304

Baldwin, S. (2006). Organizational justice. Brighton: Institute for Employment Studies.

Bakari, H., Hunjra, A. I,. \& Niazi, G. S. K. (2017). How does authentic leadership influence planned organizational change? The role of employees' perceptions: Integration of theory of planned behavior and Lewin's three step model. Journal of Change Management, 17, 155-187. doi:10.1080/14697017.2017.1299370

Baraldi, S., Kalyal, H. J., Bernston, E., Naswall, K., \&Sverke, M. (2010). The importance of commitment to change in public reform : An example from Pakistan. Journal of Change Management, 10(4), 347368.

https://doi.org/10.1080/14697017.20 10.516482

Bernerth, J. B., Armenakis, A. A., Feild, H. S., \& Walker, H. J. (2007). Justice, cynicism, and commitment: A study of important organizational change variables. The Journal of Applied Behavioral Science, 43(3), 303-326. doi:10.1177\%2F0021886306296602

Choi, M. (2011). Employees' attitudes toward organizational change: A literature review. Human Resource Management, 50(4), 479-500. doi:10.1002/hrm.20434

Cinite, I., Duxbury, L. E., \& Higgins, C. (2009). Measurement of perceived organizational readiness for change in the public sector. British Journal of Management, 20(2), 265-277. doi:10.1111/j.14678551.2008.00582.x
Colquitt, J. A. (2001). On the dimensionality of organizational justice: a construct validation of a measure. Journal of applied psychology, 86(3), 386. doi:10.1037/0021-9010.86.3.386

Day, N. (2011). Perceived pay communication, justice and pay satisfaction. Employee Relations, Vol. 33 No. 5, pp. 476-497. doi:10.1108/01425451111153862

DeConinck, J. B. (2010). The effect of organizational justice, perceived organizational support, and perceived supervisor support on marketing employees' level of trust. Journal of business research,63(12), 13491355.

doi:10.1016/j.jbusres.2010.01.003

Foster, R. D. (2010). Resistance, justice, and commitment to change. Human Resource Development Quarterly, 21(1), 3-39. doi:10.1002/hrdq.20035

Fuchs, S., \& Edwards, M. R. (2012). Predicting pro-change behaviour: The role of perceived organisational justice and organisational identification. Human Resource Management Journal, 22(1), 39-59. doi:10.1111/j.17488583.2011.00167.x

Herold, D. M., Fedor, D. B., \& Caldwell, S. D. (2007). Beyond change management: a multilevel investigation of contextual and personal influences on employees' commitment to change. Journal of Applied Psychology, 92(4), 942. doi:10.1037/0021-9010.92.4.942

Herscovitch, L., \& Meyer, J. P. (2002). Commitment to organizational change: extension of a threecomponent model. Journal of applied psychology, $\quad 87(3), \quad 474$. doi:10.1037/0021-9010.87.3.474 
Indriastuti, D., \& Fachrunnisa, O. (2019). Triple Psycho-Organizational Supports For Change Management Process. International Journal of Economics, Business and Accounting Research (IJEBAR), 3(04).

Jaros, S. (2010). Commitment to organizational change: A critical review. Journal of Change Management, 10(1), 79-108. doi:10.1080/14697010903549457

Mensah, H., Asiamah, N. and Mireku, K. (2016). The effect of organizational justice delivery on organizational commitment: Controlling for key confounding variables. Journal of Global Responsibility, Vol. 7 No. 2, pp. 196209. doi:10.1108/JGR-06-2016-0015

Machin, M. A., Fogarty, G. J., \& Bannon, S. F. (2009). Predicting employees' commitment to and support for organisational change. The Australasian Journal of Organisational Psychology, 2, 10-18. doi:10.1375/ajop.2.1.10

Mangundjaya, W.L.H (2016). Psikologi dalam Perubahan Organisasi. Jakarta: Swascita Publication.

Mangundjaya, W. L. (2013). Leadership, Readiness to change and commitment to change. In Proceedings International Management Conference (pp. 8-9)

Mangundjaya, W. L. (2015). People or trust in building commitment to change? The Journal of Developing Areas, 49(5), 67-78.

Mangundjaya, W. (2014). The role of communication, trust and justice in commitment to change. Proceeding ICEHM Conference, February 14-15, 2014. Batam, Indonesia.
Mangundjaya, W. H., \& Fachruddin, D. F. (2012). The employee's well-being during the process of merger and acquisition. Proceedings $4^{\text {th }}$ Asian Psychological Association, July 5-7, 2012. Jakarta, Indonesia.

Meyer, J. P., Srinivas, E. S., Lal, J. B., \& Topolnytsky, L. (2007). Employee commitment and support for an organizational change: Test of the three-component model in two cultures. Journal of occupational and organizational psychology,80(2), 185-211.

doi:10.1348/096317906X118685

Miao, R., Sun, J., Hou, X., \& Li, T. (2012). Job satisfaction: Linking perceived organizational support, organizational justice with work outcomes in China. Frontiers of Business Research in China, 6(2), 169-200. doi:10.3868/s070-001-0120009-2

Michaelis, B., Steigmaier, R., \& Sonntag, K. (2009). Affective commitment to change and innovation implementation behavior : The role ofcharismatic leadership and employees' trust in top management. Journal of Change Management, 9(4), 399-417. doi:10.1080/14697010903360608

Michel, A., Stegmaier, R., \& Sonntag, K. (2010). I scratch your back-you scratch mine. Do procedural justice and organizational identification matter for employees' cooperation during change?. Journal of change management, 10(1), 41-59. doi:10.1080/14697010903549432

Neves, P. (2009). Readiness for change: Contributions for employee's level of individual change and turnover intentions. Journal of Change 
Management, 9(2),

215-231. doi:10.1080/14697010902879178

Ohana,

M. and Meyer,

M. (2016).

Distributive justice and affective commitment in nonprofit organizations: Which referent matters?. Employee Relations, Vol. 38 No. 6, pp. 841-858. doi:10.1108/ER-10-2015-0197

Pasmore, W. A. (2011). Tipping the balance: Overcoming persistent problems in organizational change. In A. B. Shani, R. W. Woodman,\&W. A. Pasmore (Eds.), Research in organizational change and development (Vol. 19, pp. 259-292). Bradford: EmeraldGroup Publishing Limited. doi:10.1108/S08973016(2011)0000019011

Rogiest, S., Segers, J., \& van Witteloostuijn, A. (2015). Climate, communication and participation impacting commitment to change. Journal of Organizational Change Management. Vol. 28 No. 6, pp. 1094-1106. doi:10.1108/JOCM-062015-0101

Shin, J., Taylor, M. S., \& Seo, M. G. (2012). Resources for change: The relationships of organizational inducements and psychological resilience to employees' attitudes and behaviors toward organizational change. Academy of Management journal, 55(3), 727-748. doi:10.5465/amj.2010.0325
Stjernen, A. (2009). Perceived fairness and resistance to organizational change in relation to change-commitment. Master's Thesis. University of Oslo.

Tsai, K. L., \& Harrison, W. (2019). Organizational Actions in Gaining Employee Support for Change: The Roles of Affective Commitment to Change, Organizational Justice, and Organizational Cynicism. Journal of Organizational Psychology, 19(5). doi:10.33423/jop.v19i5.2516

Parish, J. T., Cadwallader, S., \& Busch, P. (2008). Want to, need to, ought to: employee commitment to organizational change. Journal of Organizational Change Management, 21(1), 32-52. doi:10.1108/09534810810847020

Van der Voet, J., Kuipers, B. S., \& Groeneveld, S. (2016). Implementing change in public organizations: The relationship between leadership and affective commitment to change in a public sector context. Public Management Review, 18(6), 842-865. doi:10.1080/14719037.2015.1045020

Yulianti, Y. (2017) Improving perceived organizational support, organizational justice and job satisfaction through coaching program forsupervisor. Master's Thesis in applied psychology for human resources and knowledge management. University of Indonesia. 